\title{
Laboratory testing of steel L360NB, L80, J55 resistance to sulphide stress cracking SCC and hydrogen induced cracking HIC
}

\begin{abstract}
Results of laboratory study of 3 types of steel, resistance to sulphide stress cracking and hydrogen induced cracking in $\mathrm{H}_{2} \mathrm{~S}$ environments, are presented in this article. Those steels have been applied in the petroleum industry. Determining the threshold of safety for each type of steel (with regard to yield strength $R_{e}$ ) below where stress cracking won't occur was possible owing to these examinations. Hydrogen induced cracking test was applied to research steel resistance to cracking caused by hydrogen from sulphur aqueous environments. These tests permit determination of the threshold of safety of a given material to be admitted for use in hydrogen sulphide environments.
\end{abstract}

Key words: hydrogen sulphide, stress corrosion, hydrogen induced cracking.

\section{Badania odporności stali gatunku L360NB, L80, J55 na korozję naprężeniową SCC oraz kruchość wodorową HIC}

\begin{abstract}
W artykule przedstawiono wyniki badań odporności trzech gatunków stali, stosowanych w przemyśle naftowym, na korozję naprężeniową oraz kruchość wodorową występującą w środowisku zawierającym $\mathrm{H}_{2} \mathrm{~S}$. Testy korozji naprężeniowej SCC pozwalają na określenie progu bezpieczeństwa dla danego materiału w odniesieniu do granicy plastyczności $R_{e}$, poniżej którego nie występuje siarczkowe pękanie naprężeniowe. Test kruchości wodorowej HIC stosuje się do badań odporności stali na pękanie indukowane absorpcją wodoru pochodzącego z zasiarczonego środowiska wodnego. Badania te pozwalają na określenie klasy odporności dla danego materiału dopuszczając go do pracy w środowisku siarkowodoru.
\end{abstract}

Słowa kluczowe: siarkowodór, korozja naprężeniowa, kruchość wodorowa.

\section{Introduction}

The problem of sulphide embrittlement in a hydrogen sulphide containing environment, has been known in the oil and gas industry all over the world, for many years. Such types of corrosion is especially dangerous as it may cause sudden cracks and breaks of pipelines.

Because of the increasing demand for oil and natural gas there is the necessity to use deposits of increasingly worse mining practices. The presence of hydrogen sulphide in reservoir fluid requires the use of construction materials with special properties, namely those with the least susceptibility to stress corrosion cracking and hydrogen embrittlement, strongly stimulated by this particular constituent. Hydrogen sulphide occurs naturally in crude oil and natural gas at varying amounts from as low as $1 \div 2 \mathrm{ppm}$ to high (several or even up to tens of percent in the most sulphurised deposits in the world). It can be also produced by sulphate-reducing bacteria (SRB) and in chemical processes in deposits. In anaerobic conditions sulphate ions are used as a source of oxygen in the SRB bacteria respiration process. This process requires the presence of the water phase, e.g. formation water, waste water or condensation water, etc.

SCC can be caused by mechanical stresses, even very small, that may occur in steels after cold working without following pressure relief annealing, after water cooling during 
heat treatment, after welding, and event after machining. One of characteristic features of stress corrosion is metal embrittlement demonstrating itself during tensile tests. A significant effect on sulphide stress cracking have such factors as: metallurgical conditions and strength, hydrogen ion concentration in the water phase, $\mathrm{H}_{2} \mathrm{~S}$ partial pressure, total tensile stress, temperature, exposure time to medium, galvanic effects, chloride and other halogen ions concentrations, oxidizer concentration, and non-production fluid concentration. Stress corrosion cracking occurs only in the presence of tensile stresses. The stresses resulting from stretching are added then to internal stresses caused by heat treatment.

The occurrence of hydrogen induced cracking (HIC) is related to the presence of hydrogen sulphide in formations or releasing it at higher temperatures from sulphonates (compounds used as additives to drilling fluids) or producing it by anaerobes.

Hydrogen sulphide dissolves in water, to give a slightly ionized solution.

$$
\begin{aligned}
\mathrm{H}_{2} \mathrm{~S} & \leftrightarrow \mathrm{H}^{+}+\mathrm{HS}^{-} \\
\mathrm{HS}^{-} & \leftrightarrow \mathrm{H}^{+}+\mathrm{S}^{2-}
\end{aligned}
$$

A saturated solution of $\mathrm{H}_{2} \mathrm{~S}$ in water shows $\mathrm{pH}$ about 4 and is a very weak acid. This acid reacts with iron to release hydrogen and iron (II) sulphide that precipitates on-site forming a sedimentation highly adhering to the surface.

$$
\begin{gathered}
\text { anode } \mathrm{Fe}+\mathrm{S}^{2-} \rightarrow \mathrm{FeS}+2 \mathrm{e} \\
\text { cathode } 2 \mathrm{H}^{+}+2 \mathrm{e} \rightarrow 2 \mathrm{H}
\end{gathered}
$$

In acidic solution this reaction continues and the concentration of iron (II) ions increases, while in base solution it drops to low values. The rate of corrosion decreases at $\mathrm{pH}>7$, whilst the presence of oxygen enhances the anodic process and corrosion may proceed at a higher speed. The higher the hydrogen sulphide concentration, higher formation pressure, lower $\mathrm{pH}$ and higher material susceptibility, the shorter the time to corrosion cracking. Hydrogen present in metal deteriorates its elastic properties (so called hydrogen induced cracking). This harmful phenomenon is of utmost importance for high-strength steels being commonly used in oil and gas drilling. The steels mentioned above show especially high susceptibility to hydrogen induced cracking. This susceptibility increases with increasing mechanical strength of steel. Hydrogen embrittlement does not occur at high and low temperatures, and this is specifically characteristic of such corrosion type and reaches its maximum at temperature $20 \pm 5^{\circ} \mathrm{C}[1-6,9]$.

\section{Laboratory testing}

The aim of tests was to determine the resistance of L360NB, J55 and L80 steel grades to stress corrosion and hydrogen induced cracking.

\section{Stress corrosion tests}

Test methodology

Stress corrosion cracking tests allow the safety threshold to be determined for a given material in terms of yield stress $R_{e}$, below it sulphide stress cracking does not occur.

The testing of L360NB, L80 and J55 steels was carried out by using method A according to ANSI/NACE Standard TM0177-2005 [10]. The dimensions and shape of specimens used for stress corrosion evaluation are presented in Figure 1and Table 1 [8].

Table 1. Test specimen size for stress corrosion cracking evaluation

\begin{tabular}{|c|c|c|}
\hline Dimension & Standard specimens & $\begin{array}{c}\text { Specimens of reduced } \\
\text { size }\end{array}$ \\
\hline $\mathrm{D}$ & $6.35 \pm 0.13 \mathrm{~mm}$ & $3.81 \pm 0.05 \mathrm{~mm}$ \\
\hline $\mathrm{G}$ & $25.4 \mathrm{~mm}$ & $25.4 \mathrm{~mm}$ \\
\hline $\mathrm{R}(\mathrm{min})$ & $1.5 \mathrm{~mm}$ & $1.5 \mathrm{~mm}$ \\
\hline
\end{tabular}

Due to equipment requirements, test specimens of reduced size were used.

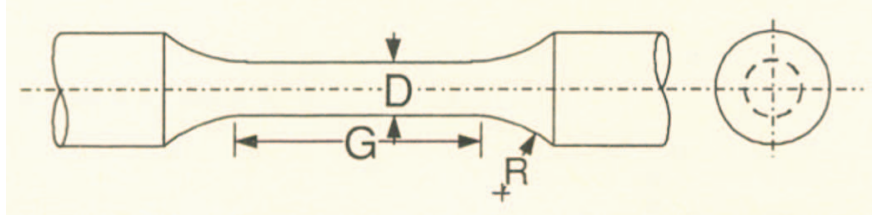

Fig. 1. Test specimen for stress corrosion cracking evaluation

A solution of $5 \% \mathrm{NaCl}+0.5 \% \mathrm{CH}_{3} \mathrm{COOH}+\mathrm{H}_{2} \mathrm{O}$ was vented by purging with nitrogen and saturated with $\mathrm{H}_{2} \mathrm{~S}$ gas for $30 \div 50$ minutes prior to testing and throughout measurements was used as the corrosive medium. The test time was 720 hours, test temperature of $23^{\circ} \mathrm{C}$, the $\mathrm{pH}$ of solution before testing was $2.6 \div 2.8$, and was kept below 4 during tests. Each specimen was placed in the measuring chamber filled with the test solution, through which hydrogen sulphide was passed. Appropriate axial stresses were applied to specimens by using a system of levers and loads. The aim of the tests was to determine a percentage of yield strength $R_{e}$, at which a specimen does not break off for at least 720 hours. The determined percentage of $R_{e}$ is the safety threshold for a given material in hydrogen sulphide environment and indicates that before this threshold 
stress the material does not crack. Prior to corrosion tests, the mean value of yield strength $R_{\text {eaver }}$ being the reference value for selecting stresses for corrosion tests, was determined based

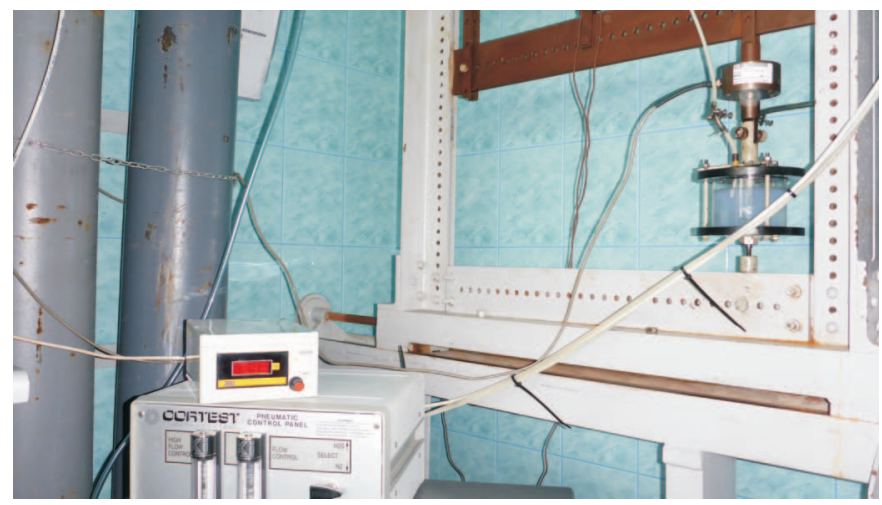

Photo 1. SCC test apparatus

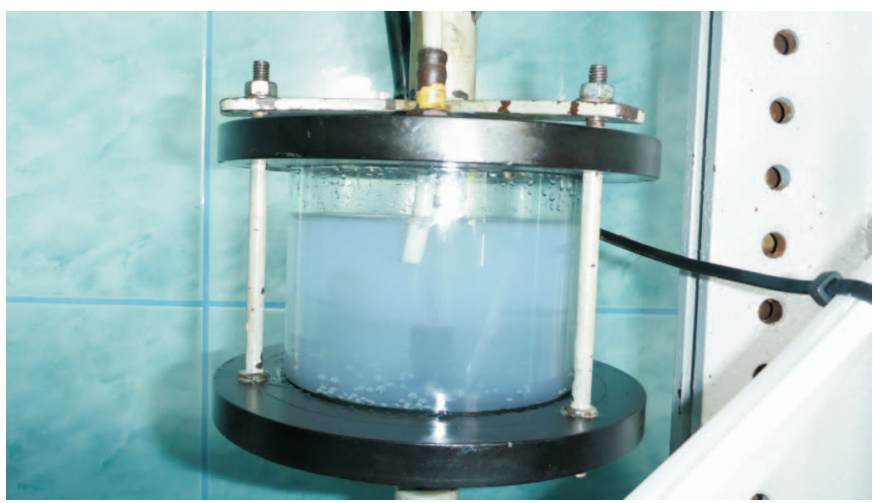

Photo 2. SCC measuring chamber on material data sheets. The specimens were then subject to stresses being a percentage of the determined value of $R_{\text {eaver }}$.

Test conditions according to NACE [10] are extreme and do not occur in industrial applications. Thus, when a specimen of specified steel grade passes the above test, such steel can be safely used in production conditions. By using the abovementioned tests, the safe stress threshold which cannot be exceeded in industrial applications was established $[7,8,10]$.

The test was carried out by using apparatus shown in Photo 1, while the measuring chamber is presented in Photo 2 .

Test results

Test results are presented in Table 2 and in photographs 3 , 4 and 5 .

The following results were obtained for individual steel grades:

- L360NB steel grade - safe operating range in the presence of hydrogen sulphide is below $54 \%$ of yield strength $R_{e}$, corresponding to stress of $212 \mathrm{MPa}$,

- L80 steel grade safe operating range in the presence of hydrogen sulphide is below $61 \%$ of yield strength $R_{e}$, corresponding to stress of $374 \mathrm{MPa}$,

- J55 steel grade - safe operating range in the presence of hydrogen sulphide is below $55 \%$ of yield strength $R_{e}$, corresponding to stress of $249 \mathrm{MPa}$.

The obtained results indicate a low resistance of tested materials. For each steel grade four specimens were tested, while stress was decreased gradually. Only the last fourth

Table 2. Results of sulphide stress cracking tests

\begin{tabular}{|c|c|c|c|c|c|c|c|c|c|c|}
\hline $\begin{array}{c}\text { Specimen } \\
\text { No. }\end{array}$ & $\begin{array}{c}O \\
{[\mathrm{~kg}]}\end{array}$ & $m_{n}$ & $\begin{array}{c}F \\
{[\mathrm{~kg}]}\end{array}$ & $\begin{array}{c}d_{0} \\
{[\mathrm{~mm}]}\end{array}$ & $\begin{array}{c}S_{0} \\
{[\mathrm{~mm}]}\end{array}$ & $\begin{array}{c}R \\
{[\mathrm{MPa}]}\end{array}$ & $\begin{array}{c}R_{\text {eaver }} \\
{[\mathrm{MPa}]}\end{array}$ & $\% R_{\text {eaver }}$ & $\begin{array}{c}t \\
{[\mathrm{~h}]}\end{array}$ \\
\hline \multicolumn{7}{|c|}{$\mathrm{L} 360 \mathrm{NB}$ steel } \\
\hline 1 & 13 & 29 & 377 & 3.81 & 11.39 & 324.50 & 391 & 82.99 & 644 \\
\hline 2 & 12 & 29 & 348 & 3.81 & 11.39 & 299.54 & 391 & 76.61 & $18 \mathrm{~h} 50 \mathrm{~min}$ \\
\hline 3 & 10 & 29 & 290 & 3.81 & 11.39 & 249.60 & 391 & 63.84 & $117 \mathrm{~h} 40 \mathrm{~min}$ \\
\hline 4 & 8.5 & 29 & 246 & 3.81 & 11.39 & 212.20 & 391 & 54.30 & 743 \\
\hline \multicolumn{7}{|c|}{ L80 steel } \\
\hline 1 & 22 & 29 & 638 & 3.81 & 11.39 & 549.0 & 615 & 89.27 & 141 \\
\hline 2 & 20 & 29 & 580 & 3.81 & 11.39 & 499.0 & 615 & 81 & 236 \\
\hline 3 & 17 & 29 & 493 & 3.81 & 11.39 & 424.3 & 615 & 69 & 215 \\
\hline 4 & 15 & 29 & 435 & 3.81 & 11.39 & 374.4 & 615 & 61 & 767 \\
\hline \multicolumn{7}{|c|}{$\mathrm{J} 55$ steel } \\
\hline 1 & 14 & 29 & 406 & 3.81 & 11.39 & 349.5 & 454 & 77 & $42 \mathrm{~h} 30 \mathrm{~min}$ \\
\hline 2 & 12 & 29 & 377 & 3.81 & 11.39 & 299.5 & 454 & 66 & 23 \\
\hline 3 & 11 & 29 & 319 & 3.81 & 11.39 & 274.5 & 454 & 60.5 & 69 \\
\hline 4 & 10 & 29 & 290 & 3.81 & 11.39 & 249.6 & 454 & 55 & 862 \\
\hline
\end{tabular}

Denotations adopted in Table 2: $O$ - test machine load, $m_{n}$ - machine multiplier, $F$ - force applied to the specimen, $d_{0}-$ specimen diameter over working length, $S_{0}$ - initial specimen cross-section in working part, $R$-stress in specimen, $R_{\text {eaver }}-$ mean value of yield strength determined from mechanical properties, $t-$ time. 
specimen resisted at least 720 hours under corrosion test conditions without any cracking traces.

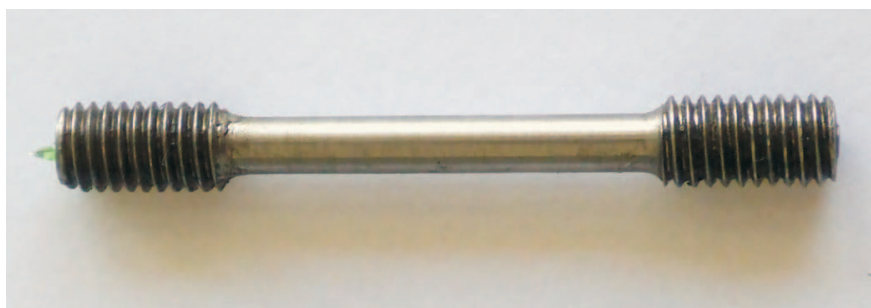

Photo 3. Example of a specimen before SCC testing

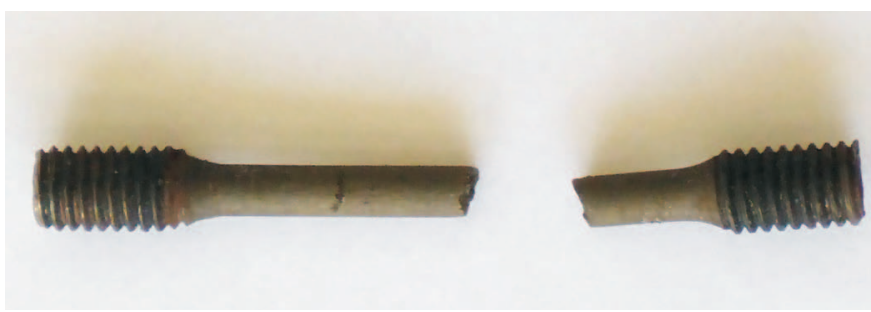

Photo 4. Example of specimen that failed SCC testing

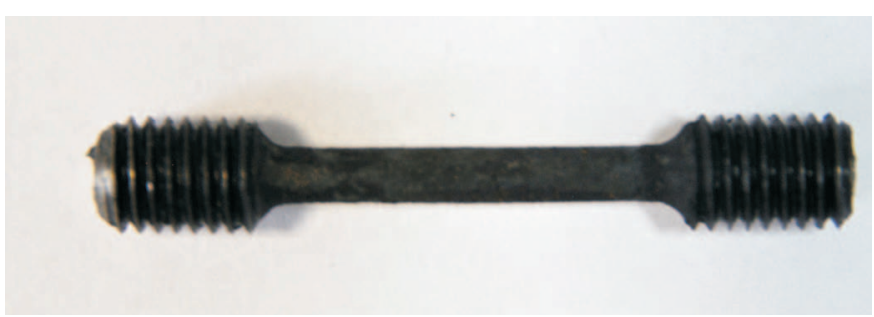

Photo 5. Example of specimen that passed SCC test

\section{Hydrogen induced cracking tests}

\section{Test methodology}

The HIC tests were carried out according to the following standards: NACE Standard TM-0284-2011 [11]. PN-EN 10229:2001 [13], PN-EN ISO 15156-2:2010 [14], PN-EN 10028-3:2010 [12].

Although the method specified in standards creates severe test conditions that in fact do not occur, the obtained results are useful for selecting materials to be used in hydrogen sulphide environment. The test according to standards listed above is used for evaluating steel resistance to cracking induced by absorption of hydrogen originated from sulphated aqueous environment. The specimens were taken from pipes made of L360NB, L80 and J55 steel grades and were of $100 \pm 1 \mathrm{~mm} \times 20$ $\pm 1 \mathrm{~mm} \times$ material thickness $\mathrm{mm}$ (length $\times$ width $\times$ thickness) in size. The main surfaces of specimens were polished with an abrasive paper, 320 grit. Prior to test the specimens were thoroughly degreased. Afterwards, the specimens were placed in the test vessel so that their surfaces parallel to the original product surface were arranged vertically. To keep the minimum distances between specimens, plexiglass pads were used (see Figure 2) $[7,8,11,13]$.

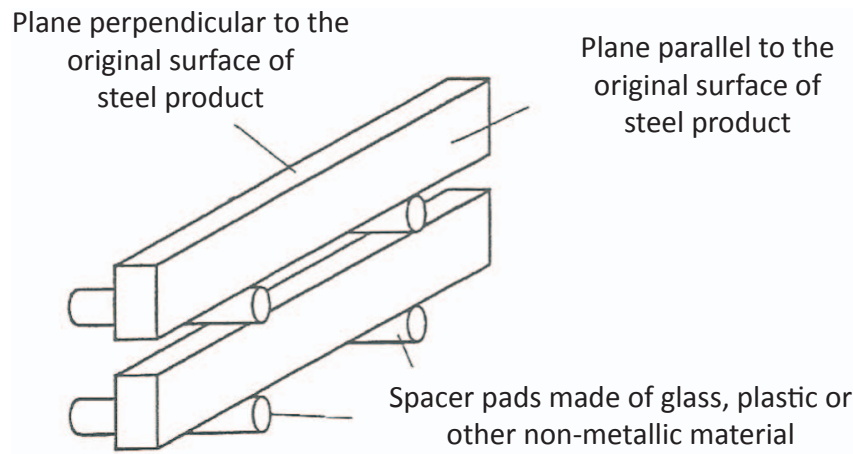

Fig. 2. Specimen placement in the test vessel

The test solution was prepared in laboratory by using analytical grade reagents according to the recipe specified in the standard which entails dissolving $50 \mathrm{~g}$ of NaCl and $5 \mathrm{~g}$ of glacial $\mathrm{CH}_{3} \mathrm{COOH}$ in $945 \mathrm{ml}$ of distilled water. The initial $\mathrm{pH}$ of the solution in individual tests was $2.7 \div 2.8$. Afterwards, the solution was vented by purging with nitrogen at a flow rate of $110 \mathrm{~cm}^{3}$ per minute and 1 litre of solution for 80 minutes. After venting the solution was saturated with $\mathrm{H}_{2} \mathrm{~S}$ at flow rate at $200 \mathrm{~cm}^{2}$ per minute for 60 minutes and the saturation level was maintained throughout the test. The final $\mathrm{pH}$ of solution was $3.5 \div 3.6$.

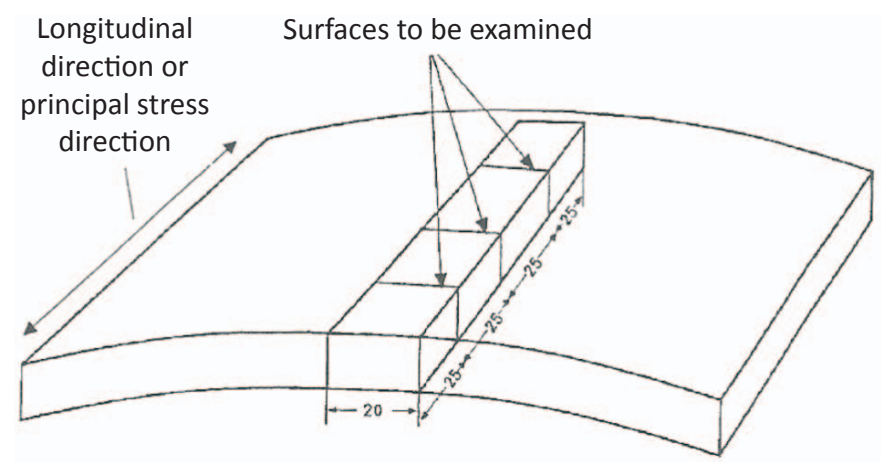

Fig. 3. Specimen division into sections and surfaces for metallographic examination

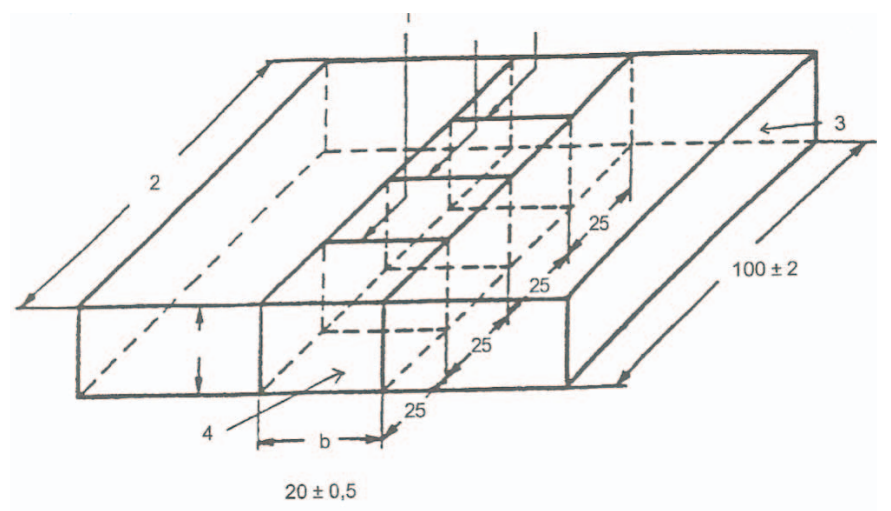

Fig. 4. Test specimen dimensions and microsection taking scheme: 1 - surfaces on which cracking evaluation is carried out, 2 - longitudinal or plastic strain direction, 3 - test section, 4 - microsection 
In first phase unencumbered specimens were exposed to the solution at $23^{\circ} \mathrm{C} \pm 2^{\circ} \mathrm{C}$ and ambient pressure, by placing them in a tightly closed vessel. After $96 \mathrm{~h}$ the specimens were removed from the solution and cleaned under a stream of running water with a plastic brush. Then, each specimen was divided into sections for metallographic examinations (Figure 3 and 4). The sections were prepared for microscopic observations by making metallographic microsections $[7,8,13,14]$.

The microscopic measurements were made at 100x magnification. They were aimed at determining hydrogen induced cracking susceptibility ratios coefficients CSR, CLR and CTR.

Crack sensivity ratio $C S R=\frac{\sum(a \cdot b)}{W \cdot T} \cdot 100 \%$

Crack lenght ratio $C L R=\frac{\sum a}{W} \cdot 100 \%$

Crack thickness ratio $C T R=\frac{\sum b}{T} \cdot 100 \%$

where:

$a$ - crack length,

$b$ - crack thickness,

$W$ - section width,

$T$ - specimen thickness.

Measurement rules and cracking evaluation methods during microscopic observations are shown in Figure 5 and $6 a-d[13]$.

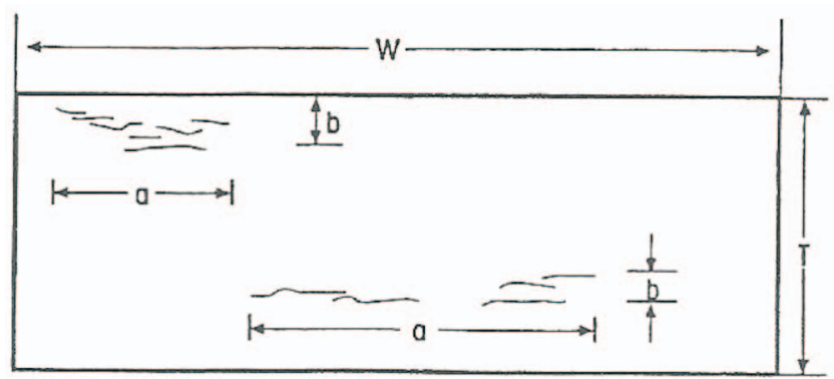

Fig. 5. Measurement rules during microscopic observations

The qualification criteria for materials to be used in hydrogen sulphide environment without stresses, pertaining to the permissible values of coefficients CLR, CSR and CTR are shown in Table 3 [12].

Table 3. Values of CLR, CTR and CSR coefficients according to PN-EN 10028-3:2009 that permit a material to be used in hydrogen sulphide environment after HIC test

\begin{tabular}{|c|c|c|c|}
\hline $\begin{array}{c}\text { Resistance } \\
\text { class }\end{array}$ & $\begin{array}{c}\text { CLR } \\
{[\%]}\end{array}$ & $\begin{array}{c}\text { CTR } \\
{[\%]}\end{array}$ & $\begin{array}{c}\text { CSR } \\
{[\%]}\end{array}$ \\
\hline I & $\leq 5$ & $\leq 1.5$ & $\leq 0.5$ \\
\hline II & $\leq 10$ & $\leq 3.0$ & $\leq 1.0$ \\
\hline III & $\leq 15$ & $\leq 5.0$ & $\leq 2.0$ \\
\hline
\end{tabular}

The test was carried out on apparatus presented in Photo 6 and 7.

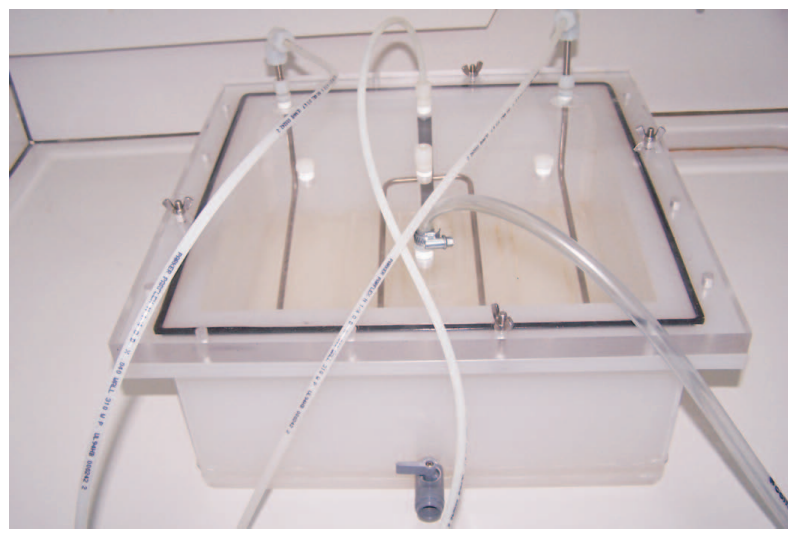

Photo 6. HIC test chamber

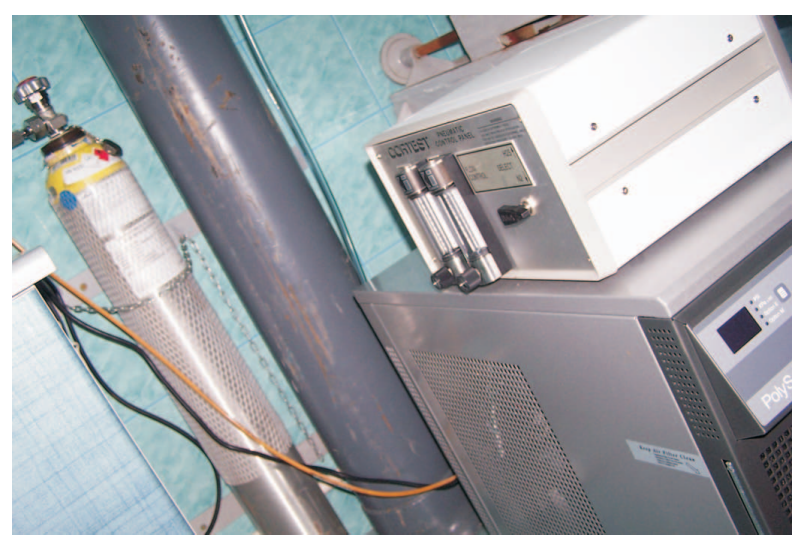

Photo 7. Equipment for maintaining HIC test conditions in the test chamber

\section{Examples}

a)

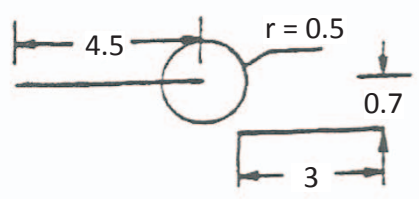

b)

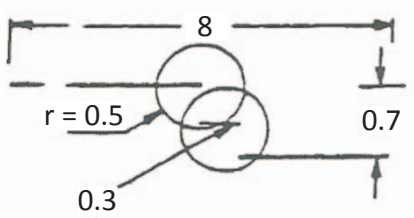

c)

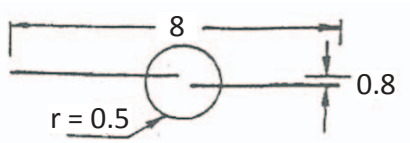

d)

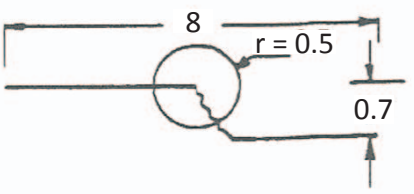

Remarks

( $d$ = distance between two cracks, mm)

$d>0.5$; two single cracks $d<0.5$; crack tip field

$d<0.10$; crack to be considered as a single crack

stepped crack (as in example b)

Fig. 6. Cracking evaluation method [13] 


\section{Test results}

The results of microscopic observations of metallurgical microsections made from steel grades under examination are presented in Table 4, while HIC test results are listed in Table 5. The exterior portion of the specimen surface showing a crack at $100 \mathrm{x}$ magnification is shown in Photo 8. The performed hydrogen induced cracking tests indicated that specimens made from L360NB, L80 and J55 steel grades had only single small cracks caused by hydrogen penetration into the metal structure.

The computed hydrogen induced cracking susceptibility ratios reached low values. The materials mentioned above

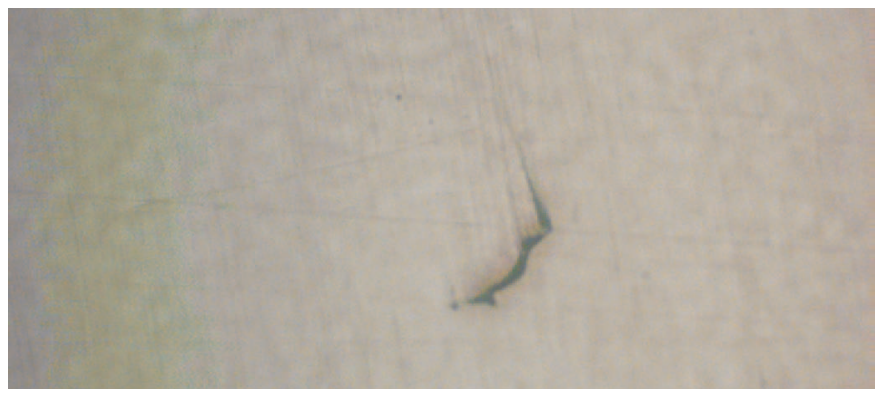

Photo 8. Crack \#1 observed on specimen 2C of L360NB steel at 100x magnification
Table 4. Results of microscopic observations of metallographic microsections made from L360NB, L80, J55 steel grades

\begin{tabular}{|c|c|c|}
\hline L360NB & L80 & $\mathrm{J} 55$ \\
\hline Specimen $1 \mathrm{~A}$ - no cracks & Specimen $10 \mathrm{~A}$ - no cracks & Specimen $4 \mathrm{~A}-$ no cracks \\
\hline Specimen $1 \mathrm{~B}$ - no cracks & Specimen $10 \mathrm{~B}$ - no cracks & Specimen 4B - no cracks \\
\hline Specimen $1 \mathrm{C}-$ no cracks & Specimen $10 \mathrm{C}-$ no cracks & Specimen $4 \mathrm{C}-$ no cracks \\
\hline Specimen $2 \mathrm{~A}-$ no cracks & Specimen $11 \mathrm{~A}-$ no cracks & Specimen $5 \mathrm{~A}-$ no cracks \\
\hline Specimen 2B - no cracks & Specimen $11 \mathrm{~B}-$ no cracks & Specimen $5 B-$ no cracks \\
\hline $\begin{array}{l}\text { Specimen } 2 \mathrm{C}-\operatorname{crack} \# 1 \\
\mathrm{a}=0.14 \mathrm{~mm}, \mathrm{~b}=0.14 \mathrm{~mm}\end{array}$ & Specimen $11 \mathrm{C}-$ no cracks & Specimen $5 \mathrm{C}-$ no cracks \\
\hline Specimen $3 \mathrm{~A}-$ no cracks & $\begin{array}{l}\text { Specimen } 12 \mathrm{~A}-\text { crack } \# 1 \\
\mathrm{a}=0.15 \mathrm{~mm}, \mathrm{~b}=0.05 \mathrm{~mm}\end{array}$ & Specimen $6 \mathrm{~A}-$ no cracks \\
\hline $\begin{array}{l}\text { Specimen } 3 \mathrm{~B}-\text { crack \#1 } \\
\mathrm{a}=0.04 \mathrm{~mm}, \mathrm{~b}=0.06 \mathrm{~mm}\end{array}$ & Specimen $12 \mathrm{~B}$ - no cracks & Specimen $6 \mathrm{~B}-$ no cracks \\
\hline Specimen $3 \mathrm{C}-$ no cracks & $\begin{array}{l}\text { Specimen } 12 \mathrm{C}-\text { crack } \# 1 \\
\mathrm{a}=0.20 \mathrm{~mm}, \mathrm{~b}=0.57 \mathrm{~mm}\end{array}$ & Specimen $6 \mathrm{C}-$ no cracks \\
\hline
\end{tabular}

are highly resistant to hydrogen induced cracking and are placed in resistance class I.

Table 5. HIC test results for individual materials

\begin{tabular}{|c|c|c|c|c|}
\hline Material & $\begin{array}{c}\text { CLR } \\
{[\%]}\end{array}$ & $\begin{array}{c}\text { CTR } \\
{[\%]}\end{array}$ & $\begin{array}{c}\text { CSR } \\
{[\%]}\end{array}$ & $\begin{array}{c}\text { Criteria } \\
\text { fulfilment }\end{array}$ \\
\hline L360NB steel & 0.100 & 0.252 & 0.001 & $\begin{array}{c}\text { yes } \\
\text { class I }\end{array}$ \\
\hline L80 steel & 0.194 & 1.378 & 0.013 & $\begin{array}{c}\text { yes } \\
\text { class I }\end{array}$ \\
\hline J55 steel & 0.000 & 0.000 & 0.000 & $\begin{array}{c}\text { yes } \\
\text { class I }\end{array}$ \\
\hline
\end{tabular}

\section{Summary}

The tested L360NB, L80 and J55 steel grades demonstrated a very good resistance to brittle cracking caused by hydrogen penetration into the metal structure (HIC). All these steels are classified in resistance class I, and its hydrogen induced cracking susceptibility ratios are close to $0 \%$.
However, the thresholds of permissible stresses determining safe working conditions for materials under examination, below which sulphide stress cracking (SCC) does not occur, are relatively low and are $54 \%, 61 \%$ and $55 \%$ of yield strength for L360NB, L80 and J55 steel grades, respectively.

Please cite as: Nafta-Gaz 2015, no. 11, pp. 917-923, DOI: 10.18668/NG2015.11.15

Article contributed to the Editor 31.08.2015. Approved for publication 6.10.2015.

The article is the result of research conducted in connection with a project: Development of optimum concepts for unconventional deposits management, considering environmental and social aspects, co-funded by the National Centre for Research and Development as part of the programme BLUE GAS - POLISH SHALE GAS. Contract No. BG1/ResDev/13.

\section{Literature}

[1] Bastien P., Weron H.: Special steels resistant to stress corrosion by hydrogen sulfide. Revue doe Metalurgic Memoires 1958, vol. 55.

[2] Burk J. D.: Hydrogen-Induced Cracking in Surface Produc- tion Systems: Mechanism, Inspection, Repair and Prevention. SPE 1996, vol. 11(1), pp. 49-53. DOI: 10.2118/25583-PA.

[3] Butnicki S.: Spawalnosc i kruchosc stali. Wydawnictwa Naukowo-Techniczne, Warszawa 1979. 
[4] Korozja metali i stopow. Pod red. L. L. Shreira. Wydawnictwa Naukowo-Techniczne, Warszawa 1966.

[5] Praca zbiorowa pod redakcją J. Flisa: Wodorowe i korozyjne niszczenie metali. Państwowe Wydawnictwo Naukowe, Warszawa 1979.

[6] Rzepka M.: Badania odpornosci korozyjnej stwardnialych zaczynow cementowych stosowanych do uszczelniania rur okladzinowych $w$ warunkach dzialania siarkowodoru. Nafta-Gaz 2013, no. 7, pp. 515-524.

[7] Stachowicz A.: Badania korozji naprezeniowej stali w srodowisku siarkowodoru w przemysle naftowym. Wiadomości Naftowe i Gazownicze 2013, no. 12, pp. 9-11.

[8] Stachowicz A.: Laboratoryjne badania odpornosci blach ze stali P355 na kruchosc wodorowa HIC. Wiadomości Naftowe i Gazownicze 2014, no. 11, pp. 10-14.

[9] Turkiewicz A., Kania M., Janiga M.: Badania mikrobiologiczne $i$ analizy chemiczne zawartosci zwiazkow siarki w mediach zlozowych pochodzacych $z$ warstw solnych obiektu magazynowania gazu ziemnego. Nafta-Gaz 2013, no. 8, pp. 588-598.

\section{Legal and normative acts}

[10] ANSI/NACE Standard TM0177-2005 Item No. 21212 Standard Test Method. Laboratory Testing of Metals for Resistance to Sulfide Stress Cracking and Stress Corrosion Cracking in $\mathrm{H}_{2} \mathrm{~S}$ Environments.
[11] NACE Standard TM-0284-2011 Item No. 21215 Evaluation of Pipeline and Pressure Vessel Steels for Resistance to Hydrogen-Induced Cracking.

[12] PN-EN 10028-3:2010 Wyroby ptaskie ze stali na urzadzenia ciśnieniowe - Część 3: Stale spawalne drobnoziarniste normalizowane.

[13] PN-EN 10229:2001 Ocena odporności wyrobów stalowych na pękanie wywotane wodorem (HIC).

[14] PN-EN ISO 15156-2:2010 Przemyst naftowy, petrochemiczny i gazowniczy. Materiaty stosowane przy wydobyciu ropy i gazu w środowisku zawierającym $\mathrm{H}_{2} \mathrm{~S}$. Czesść 2: Stale niestopowe i niskostopowe odporne na pękanie oraz stosowanie żeliw.

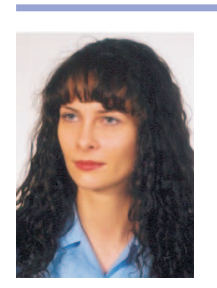

Agnieszka STACHOWICZ M.Sc. Eng.

Senior Research and Technical Specialist

Department of Hydrocarbons Production Stimulation

Oil and Gas Institute - National Research Institute

ul. Lubicz 25 A

31-503 Kraków

E-mail: agnieszka.stachowicz@inig.pl

\section{OFFER}

\section{DEPARTMENT OF RESERVOIR STIMULATION}

Scope of activity:

- design and testing of fracturing and acidizing fluids for stimulation of oil and gas reservoirs;

- flow simulation and rheological testing in semi-technical test conditions;

- proppant testing;

- fracture conductivity of different proppants, conductivity damage and conductivity regain testing;

- modeling of near-wellbore damage removal;

- determination of permeability and porosity for rocks, cement and other porous materials;

- selection of specific additives to improve the rheological properties of stimulation fluids, suffactans, crosslinkers etc.;

- measurements of the rocks and acidizing fluids reaction rate;

- laboratory simulation of acidizing treatments;

- designing of stimulation treatments;

- mini frac analysis and post treatment evaluation;

- laboratory simulations of EOR technologies;

- laboratory research and testing of corrosion in oil and gas industry;

- selection of the corrosion inhibitors for oil and gas industry. 